に $0.03 \sim 0.05 \mathrm{~cm}, F は 10 \mathrm{~cm}, \mathrm{R}$ は $1.14 \mathrm{~cm}$ で ${ }^{99 \mathrm{~m}} \mathrm{Tc}$ Line source によるFWHM は空中で $1.1 \mathrm{~cm}$ ，水中では $1.2 \mathrm{~cm}, F W H M$ の最屯良い深さは空中では $9 \mathrm{~cm}$, 水 中では $7.5 \mathrm{~cm}$ で感度は従来の 85 hole の 2 倍であった。

このコリメータの使用により従来 85 hole 使用の際に 低計数值であった 4 時間後の脳スキャンが良好になうた。

\section{EMI スキャナCT-1000の5ケ月間の使用経験}

秋田具立脳血管研究七ン夕 放射線科

○蜂谷 武畫・相沢 康夫・菅, 幹雄 小野寺 洋・生司 安明・传々朴信夫 羽上栄一

当院の䫓部專用CT, EMIスキャナCT-100005ケ月間 の使用経験について検查の内容, 故障を索とめて報告し た.との結果検査件数 768 件中外来検查は $57 \%$ ，他施設 からの依頼検查は13\%で造影剂の使用は全件数の36\%で あった５0年と51年の同時期の他の神経放射線検查の動 向については脳血管造影が17\%，PEG \& PVGが20\%。 脳スキャンが36\%それぞれ減少していた。

故障は，(1)メカ的故障11件. (2)コンピュータ1件. (3) 磁氮DISC のプログラム 2 件. (4)ラインプリンタ 2 件. (5)イプライタ1件であった。，使用上の閪題点も示し， 実際のスキャン像については脳硬塞，脳出血，脳腫㾃を あげた。

\section{$\diamond$ 関東・東京部会（第23回）}

\section{日時 昭和51年10月23 - 24日 \\ 会場 神奈川県立勤学会館 特別講演 \\ 「コンピュータートモグラフイについて」 \\ 北里大学放射線科教授 橋本 省三先生 \\ 「診療放射線技即之人間関係」

$$
\text { 元 NHKアナウンサ 今福、视先生 }
$$ \\ 一般研究発表}

\section{1. 左冠状動脈近位部の撮影}

日本医科大学附属病院

緑川 正人・浜口 雄慈・川村”義彦

敛术沟・瀬川登暿男

左冠状動脈の近位部, 動脈本幹, 前下行枝, 回旋枝, 対角枝の解剖学的な形態，被检者の硬化性変化の強度们 より従来の横軸方向回転角度の変化のみでは十分な情報 を得難しケースが見られます。我々は骖断情報の向上の 為被検者の縦軸方向にX線管を回転し上記 3 枝の分離を 目的之す万撮影， RAO $30^{\circ}$ 体位，縦蟿足頭方向 $0 \sim 45^{\circ}$, $\mathrm{LAO} 60^{\circ}$ 体位，頭足方向 0 ４5 の連続撮影を行った。
その結果，前下行枝，対角枝，回旋枝の分離に有用で西 り，特江前下行枝中枢側の病変例に径し最も有用性がう かがわれた. 又左冠動脈近位部の血管走行シェーマを立 体的に把握し，各血管間走行角度之X線射入角度の相関 々孫を検索すると共洫管の動態速度による撮影の時間 的因子，X線の射入による像の正み，拡大等の因子を検 討し縦軸射入角度 $25 \sim 30^{\circ}$ を得た。

\section{2. 千葉県がんセンターにおける眼窩静脈撮影法の検討} 第 2 報

干䈎県がえセンタ一彰断部 永井、義衛 我々は先の第21回日本放射線技術学会関菓東京部会に おるつて眼窩内矣患に重要な情報を提供するこの検査法の 手技や撮影体位，主に前後像におけるX線入射角度及び 入射点を実験検討を行い報告した、今回注残る軸方向撮 影，側面撮影について実験検討を行いX線入射角度及び 入射点の最良点を導きだした。

これをもとに三方向血管像のシェーマを作成し病変の 部位の図式化又各方向所見の関連づけの作成を進めてい る.

以上の様に眼窝静脈撮影法に求いて体位，X線入射角 度，入射点を確立したことに上り病変の部位及び拡がり の変化を立体的に正確にとらえる事ができる様になっ た．又症例によっては連続拡大立体撮影を導入しより診 断能の向上につとめている.

\section{質問}

演題名についての意見ですが，演題名に自分の施設名 を入れるかわりにあう少し内容を表わすような題名にし た方があとから見る人が演題名で内容がわかると思うの ですが，例えば，何像何像の入射角之入射点の検討之か よ゙うでしようか.

斉藤（東京）

答

でもっともだと思います。今後そうしたいと思います。

\section{3. 経口胆囊造影法の一考察}

横浜古立大学医学部病院中央放射線部

○木村 秀夫・伊津兒栄重・根元 麦生

桜井博・佐々木健二・渡辺好一

红舘 節男・三谷，虔博・真洲 顕彰

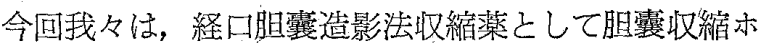
ルモンと同生理作用を成す Ceosunin 注 $0.3 \mu \mathrm{g} / \mathrm{kg}$ を入

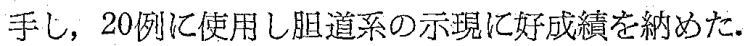

[方法・結論]

筇注後第 2 回撮影を施行（立位・腹臥位）其の後頭低 側卧位腹式呼吸60秒，一続小乙仰卧位 LAO $20^{\circ} 30^{\circ}$ ，頭低 腹臥位LAO，半立位LAO を腹式呼吸，及び重力による 